\title{
Solar combined cooling, heating and power systems based on hybrid PVT, PV or solar-thermal collectors for building applications
}

\author{
María Herrando a, b, *, Antonio M. Pantaleo ${ }^{\text {a, c }}$, Kai Wang a , Christos N. Markides ${ }^{a}$ \\ ${ }^{a}$ Clean Energy Processes (CEP) Laboratory, Department of Chemical Engineering, Imperial College London, London, UK \\ ${ }^{\mathrm{b}}$ Fluid Mechanics Group, University of Zaragoza, Zaragoza, Spain \\ ${ }^{\mathrm{c}}$ Department of Agro-Environmental Sciences, University of Bari, Italy
}

\section{A R T I C L E I N F O}

Article history:

Received 27 November 2018

Received in revised form

6 April 2019

Accepted 2 May 2019

Available online 3 May 2019

\section{Keywords:}

Absorption chiller

Economic analysis

Energy demand

Hybrid PVT

PV system

Solar collector

\begin{abstract}
A B S T R A C T
A modelling methodology is developed and used to investigate the technoeconomic performance of solar combined cooling, heating and power (S-CCHP) systems based on hybrid PVT collectors. The building energy demands are inputs to a transient system model, which couples PVT solar collectors via thermal store to commercial absorption chillers. The real energy demands of the University Campus of Bari, investment costs, relevant electricity and gas prices are used to estimate payback times. The results are compared to: evacuated tube collectors (ETCs) for heating and cooling provision; and a PV-system for electricity provision. A 1.68-MWp S-CCHP system can cover $20.9 \%, 55.1 \%$ and $16.3 \%$ of the space-heating, cooling and electrical demands of the Campus, respectively, with roof-space availability being a major limiting factor. The payback time is 16.7 years, 2.7 times higher than that of a PV system. The lack of electricity generation by the ETC-based system limits its profitability, and leads to 2.3 times longer payback time. The environmental benefits arising from the system's operation are evaluated. The S-CCHP system can displace 911 tons $\mathrm{CO}_{2} /$ year ( $16 \%$ and $1.4 \times$ times more than the PV-system and the ETC-based system, respectively). The influence of utility prices on the systems' economics is analysed. It is found that the sensitivity to these prices is significant.
\end{abstract}

๑) 2019 Elsevier Ltd. All rights reserved.

\section{Introduction}

Fossil fuels are considered important primary energy resources that have acted to satisfy the growing energy demand worldwide, which is attributed to population growth and industrialization [1,61]. It is estimated that in 2035 more than $80 \%$ of the energy consumption in developed countries will be satisfied by fossil fuels [2]. An increased penetration of renewable energy into the energy infrastructure can play a central role in shifting this trend towards a more sustainable and cleaner energy future [3]. The building sector is associated with a significant share of the total energy consumption, e.g., it accounts for over $40 \%$ of the total energy consumption while generating $36 \%$ of the greenhouse emissions in Europe [4]. However, the energy demand in buildings still relies heavily on fossil fuels. For example, only $16 \%$ of the energy for heating and cooling is covered by renewable energy, the majority of

\footnotetext{
* Corresponding author. Clean Energy Processes (CEP) Laboratory, Department of Chemical Engineering, Imperial College London, London, UK.

E-mail address: mherrando@unizar.es (M. Herrando).
}

which arises from biomass combustion with a smaller contribution from modern renewables, including solar thermal and geothermal energy [5].

Solar heating and cooling (SHC) technologies, as part of wider efforts for decarbonisation, can provide heating, including space heating (SH) and domestic hot water (DHW), as well as cooling, thus increasing the renewable energy share and reducing the dependence on fossil fuels and the associated emissions [62]. Recently, they have been gaining increasing attention and research efforts [6]. Different types of solar thermal (ST) collectors, namely flat plate (FPC), evacuated tube (ETC), parabolic trough (PTC), etc., can be used to harvest solar energy in SHC and/or solar power systems $[7,8]$.

An alternative to SHC systems based on ST collectors relies on PV systems coupled to electrically-driven reversible heat-pump/chiller $(\mathrm{HP} / \mathrm{CH})$ units $[9,10]$, which can provide both space heating/cooling depending on the operation mode. Furthermore, the synergistic combination of PV and ST collectors has given rise to hybrid photovoltaic-thermal (PVT) systems, which appear as highly suitable solutions, as they combine the advantages of PV and ST systems, generating both electricity and a useful thermal output 


\begin{tabular}{|c|c|c|c|}
\hline \multicolumn{2}{|c|}{ Nomenclature } & $\begin{array}{l}\text { ST } \\
\text { LCC }\end{array}$ & $\begin{array}{l}\text { Solar thermal } \\
\text { Life cycle cost }\end{array}$ \\
\hline \multicolumn{2}{|c|}{ Abbreviations } & Symbo & \\
\hline $\mathrm{AbCH}$ & Absorption chiller & $A_{c}$ & PVT collector aperture area $\left(\mathrm{m}^{2}\right)$ \\
\hline $\mathrm{AdCH}$ & Adsorption chiller & $A_{\mathrm{cT}}$ & Total PVT collector area in each parallel system $\left(\mathrm{m}^{2}\right)$ \\
\hline $\mathrm{COP}$ & Coefficient of performance & $c_{\mathrm{e}}$ & Electricity price $(€ / \mathrm{kWh})$ \\
\hline CPVT & Concentrated PVT & $c_{\text {ng }}$ & Natural gas price $(€ / \mathrm{kWh})$ \\
\hline CS & Cost savings & $C_{0}$ & Investment costs $(€)$ \\
\hline $\mathrm{DC} / \mathrm{AC}$ & Direct current/alternating current & $C_{\mathrm{O} \& \mathrm{M}}$ & Operation and maintenance $(\mathrm{O} \& \mathrm{M})$ costs $(€ / \mathrm{yr})$ \\
\hline DHW & Domestic hot water & $d$ & Discount rate $(\%)$ \\
\hline ESCO & Energy services company & $E_{\mathrm{Cov}}$ & Electricity demand covered (kWh) \\
\hline ETC & Evacuated tube collector & $E_{\text {grid }}$ & Electricity exported to the grid (kWh) \\
\hline FIT & Feed-in-tariff & $I_{\text {tot }}$ & Total global solar irradiance $\left(\mathrm{W} / \mathrm{m}^{2}\right)$ \\
\hline FPC & Flat plate collector & $i_{\mathrm{F}}$ & Fuel inflation rate $(\%)$ \\
\hline $\mathrm{HP} / \mathrm{CH}$ & Heat-pump/chiller & $I_{\mathrm{SC}}$ & Open circuit current $(\mathrm{A})$ \\
\hline HVAC & Heating ventilation and air conditioning & $n$ & Node $(-)$ \\
\hline IEA & International Energy Agency & $q_{\mathrm{u}}$ & Useful heat flow per meter square $\left(\mathrm{W} / \mathrm{m}^{2}\right)$ \\
\hline $\mathrm{pc}-\mathrm{Si}$ & Poly-crystalline silicon PV module & $Q_{\text {Cov }}$ & SH demand covered $(\mathrm{kWh})$ \\
\hline O\&M & Operation and maintenance costs & $T_{\mathrm{a}}$ & Ambient temperature $(\mathrm{K})$ \\
\hline PC & Polycarbonate & $T_{\mathrm{fm}}$ & Fluid mean temperature (K) \\
\hline PBT & Payback time & $T_{\mathrm{r}}$ & Reduced temperature $(\mathrm{K})$ \\
\hline PTC & Parabolic trough collector & $V_{\mathrm{t}}$ & Storage tank volume (L) \\
\hline PV & Photovoltaic & $V_{\mathrm{oc}}$ & Open circuit voltage (V) \\
\hline PVT & Photovoltaic-thermal system & & \\
\hline S-CCHP & Solar combined cooling, heating and power & Greek & \\
\hline S-CHP & Solar combined heating and power & $\eta_{\text {boil }}$ & Boiler efficiency (\%) \\
\hline $\mathrm{SH}$ & Space heating & $\eta_{\mathrm{el}}$ & Electrical efficiency (\%) \\
\hline SHC & Solar heating and cooling & $\eta_{\text {th }}$ & Thermal efficiency (\%) \\
\hline
\end{tabular}

simultaneously from the same aperture area [11], with a higher overall efficiency than separate stand-alone systems [12,13]. The integration of PVT systems with heating and cooling technologies allows the simultaneous generation of DHW, SH, cooling and electricity, and thus has the potential to cover a significant amount of the energy demands of buildings [14].

Most of the studies in literature have focused on integrating ETC $[15,16]$, FPC $[17,18]$ or PTC $[19,20]$ with absorption $(\mathrm{AbCH})$ or adsorption chillers (AdCH). ETC-based SHC systems have attracted more attention as they have a better temperature match with $\mathrm{AbCH}$ (ETCs reach higher fluid temperatures) [21] with relatively lower costs [22]. Previous studies were mainly focused on component design [23], system integration [24], technology comparison [25], parametric analyses [26] and optimisation [27], performance assessment and applications [7]. There are also some studies that have considered compound parabolic concentrators coupled to single/double effect $\mathrm{LiBr}-\mathrm{H}_{2} \mathrm{O}$ AbCH $[28,29]$ or coupled to $\mathrm{AdCH}$ [30]; while other authors have analysed solar desiccant and evaporative cooling (DEC) systems [31]. Most of the studies concerned with PVT systems have focused on combining concentrated PVT (CPVT) collectors with $\mathrm{LiBr}-\mathrm{H}_{2} \mathrm{O} \mathrm{AbCH}[32,33]$, while studies on flatplate PVT collectors are scarcer [34,35]. However, previous research concluded that the integration of PVT-water collectors with $\mathrm{AbCH}$ or AdCH is very promising [6].

Despite its potential, there are still very few companies worldwide commercialising PVT collectors [36], which in most cases do not have optimised designs. In an attempt to overcome this, previous work by the authors [23] focused on the design and characterisation of novel designs based on a flat-box structure and polymeric materials for flat-plate PVT collectors. Promising results were obtained, with a polycarbonate flat-box design achieving $4 \%$ higher optical efficiency and $\sim 16 \%$ lower heat-loss coefficient than those of an equivalent commercial sheet-and-tube PVT collector, also with $10 \%$ lower weight and about $20 \%$ lower capital cost.

Previous research on a wider solar combined heating and power (S-CHP) system based on these polycarbonate flat-box PVT collectors also showed promising results for the simultaneous provision of SH, DHW and power to single-family homes [37]. Reasonable-toattractive payback times (PBT) were obtained for these S-CHP systems installed in Mediterranean cities such as Athens (15.6 years) or Zaragoza (11.6 years) [37]. Sensitivity analyses on the economics of these systems concluded that in reasonable future scenarios (e.g. $10 \%$ reduction in the PVT collector price and storage tank price, $20 \%$ reduction in the installation costs, fuel inflation rates of $3.5 \%$ ) the PBT can decrease to $\sim 10$ years [38].

This research aims to go beyond the aforementioned studies, by investigating the integration of such polycarbonate flat-box PVT collectors with $\mathrm{AbCH}$ units (single-effect $\mathrm{LiBr}-\mathrm{H}_{2} \mathrm{O}$ ) via thermal stores in wider solar systems for the combined provision of $\mathrm{SH}$, cooling and electricity to buildings. As a case study, the real monthly natural gas consumption and quarter-hourly electricity load profiles of the University Campus of Bari (Italy) are selected, in order to estimate hourly SH, cooling and electricity demands. These demands are then used as inputs to a transient model, along with real hourly weather data, to conduct year-round simulations. The performance data of a commercially available $\mathrm{AbCH}$ unit manufactured by MAYA [39] is also integrated into the transient model. The costs of the system's components, the system installation costs, as well as key economic parameters (e.g. discount rate, fuel inflation rate, utility prices) are considered in order to assess the technoeconomic feasibility of the proposed solar combined cooling, heating and power (S-CCHP) system. The results are then compared to two alternative solar systems: i) ETC-based SHC system for the provision of heating and cooling, but without power generation; 
and ii) a PV system that matches the electricity demand of the Campus (including the electricity required to run the current HVAC system for air-conditioning), but without thermal energy generation.

\section{Methodology}

The proposed PVT-based S-CCHP system, as well as the alternative ETC-based SHC system, have been modelled in TRNSYS [40], in transient simulations considering real weather data [41], conducted in hourly time-steps over a year. For the purpose of this analysis, faster transients are neglected [63]. The main outputs are the energy generated by the solar collectors (electricity and thermal energy in the case of PVT collectors, and thermal energy in the case of the ETCs), the SH, cooling and electricity demands that can be covered by the systems, and the auxiliary heating (natural gas) needs. Current electricity and natural gas prices are considered in order to estimate the annual cost savings which, together with the investment cost and the operation and maintenance costs (O\&M), allow an estimation of the system's payback time (PBT). The existing scenario of gas-fired boilers operated within an Energy Service Contract by an ESCO for the provision of $\mathrm{SH}$ is considered to estimate the avoided costs of thermal energy with the S-CCHP/SHC systems. The electricity generation surplus of the S-CCHP system at any time step is fed to the grid at a feed-in tariff (FIT) guaranteed by the distribution system operator according to current Italian regulations [42]. The annual $\mathrm{CO}_{2}$ emission reductions and primary energy savings that arise from the proposed system's operation are evaluated based on the corresponding $\mathrm{CO}_{2}$ emission and primary energy factors for electricity and natural gas in Italy.

A limiting factor for the size of the systems is the available roofspace in the Campus' buildings $\left(23,600 \mathrm{~m}^{2}\right)$. For comparison purposes, the proposed PVT-based S-CCHP system and the PV system have the same installed electrical capacity. The maximum number of PVT collectors that can be installed is 7,020, which corresponds to a total area of $10,850 \mathrm{~m}^{2}$ and an installed electrical capacity of $1.68 \mathrm{MW}_{\mathrm{p}}$. Based on previous studies [43] and preliminary analysis, the selected $V_{\mathrm{t}} / A_{\mathrm{cT}}$ ratio for the storage tank volume is $50 \mathrm{~L} / \mathrm{m}^{2}$. The PV system of the same installed power $\left(1.68 \mathrm{MW}_{\mathrm{p}}\right)$, comprises $8,830 \mathrm{~m}^{2}$ of PV modules. For the ETC-based SHC system, the same installed area as the PVT-based S-CCHP system is considered for comparison purposes, which corresponds to 3920 ETCs (ETC unitary size of $2.77 \mathrm{~m}^{2}$ [44]).

\subsection{Energy demand of the University Campus of Bari}

The Campus consists of 12 university buildings with a heated area of $127,300 \mathrm{~m}^{2}$ and a heated volume of $495,300 \mathrm{~m}^{3}$ (Fig. 3 left). The SH demand is $28.8 \mathrm{kWh} / \mathrm{m}^{2}$-year, currently covered by gasfired boilers of $82 \%$ efficiency and a hot water delivery temperature of $80^{\circ} \mathrm{C}$, with an annual consumption of $393,000 \mathrm{Nm}^{3}$ of natural gas. The DHW demand is negligible. The cooling demand is estimated to be $11.9 \mathrm{kWh} / \mathrm{m}^{2}$-year, currently covered by HVAC systems. The total electricity demand of the Campus is about $11 \mathrm{GWh}$ /year. Subtracting the electricity consumed by the HVAC systems for air-conditioning, the rest of the electricity consumption is $85.2 \mathrm{kWh} / \mathrm{m}^{2}$-year. Fig. 1 shows the monthly energy demand breakdown of the Campus. It should be noted that space heating (SH) and cooling demands shown in Fig. 1 refer to thermal-energy demands (e.g. without considering the HVAC and gas boiler systems' efficiency).

Only monthly natural gas bills are available, so based on the information provided by the Campus heating system operator (Enel Distribuzione), a flat profile from 8 a.m. to 6 p.m. (10 h/day) from Monday to Friday is assumed to estimate the hourly SH demand,

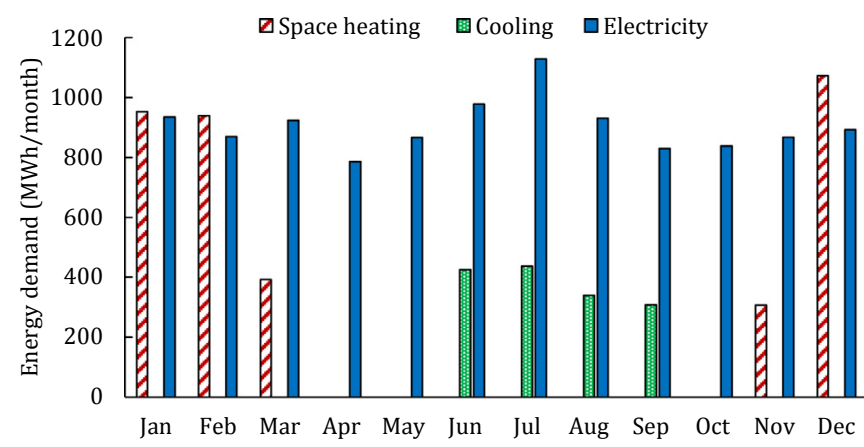

Fig. 1. Monthly space heating, cooling and electricity demands of the University Campus of Bari.

from November to March. Quarterly-hour data is available for the total electricity consumption from the local distribution system operator (Enel Distribuzione), which is aggregated to estimate the hourly electricity consumption. To estimate the cooling demand, based on previous studies [45,46], it is assumed that during summer (June to September), around 35\% of the total electricity consumption is consumed by the HVAC systems for air-conditioning from 8 a.m. to 8 p.m. ( $12 \mathrm{~h} /$ day). A COP of 3 is assumed when converting the electricity consumed by HVAC systems to cooling demand. Instead of using a flat profile, the hourly cooling demand is estimated following a distribution profile correlated to the ambient temperature (e.g. higher cooling needs around midday, 11 a.m.-3 p.m., when ambient temperatures are higher). These hourly SH, cooling and electricity demands are inputs to the transient model.

\subsection{PVT-based combined cooling, heating and power system}

Due to the considerable size and energy demand of the University Campus of Bari (12 buildings throughout the city of Bari, as shown in Fig. 3), the total number of PVT collectors is divided in 45 parallel solar combined cooling, heating and power (S-CCHP) sections of the same size, each of them with its DC/AC inverter and connected to the internal MV grid of the Campus. This facilitates operation and maintenance, and allows the systems to run according to the Campus needs while limiting the sizes of the different components (e.g. storage tanks and absorption chillers). Considering the latitude of Bari, the PVT collectors are titled at $35^{\circ}$, facing south, and are connected in parallel so that all of them have the same inlet water temperature and water flow-rate. Based on previous studies [14,37], a constant PVT collector flow-rate of $50 \mathrm{~L} / \mathrm{h}$ is assumed.

In the proposed S-CCHP system, the thermal output of the PVT collectors is connected, through a water storage tank, to the current gas-fired boilers and is used to preheat the water to satisfy the $\mathrm{SH}$ demand, reducing the gas consumption. In normal operation, the collector outlet flow enters the heat exchanger coil located inside the storage tank, heats the water in the tank, exits from the lower part of the tank and returns to the PVT collector inlet to be heated again. As shown in Fig. 2, a bypass valve is required to control the outlet temperature of the cooling fluid to ensure that this stream only heats (and does not cool) the water in the tank [11,37]. A differential temperature controller (Type $2 \mathrm{~b}$ ) controls the valve position by comparing the temperature at the entrance of the heat exchanger coil at the top of the water storage tank with the temperature of the cooling fluid at the PVT collector outlet. The electricity required to run the circulator pump of this active closed loop system is extracted from the electricity generated by the PVT 


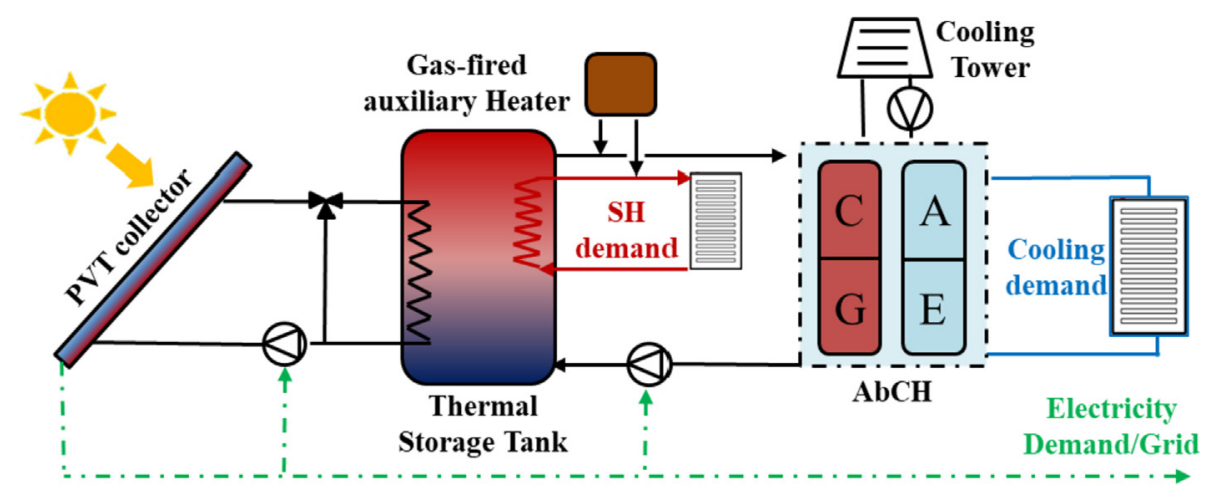

Fig. 2. Schematic diagram of an S-CCHP system based on PVT collectors integrated with a single-effect $\mathrm{LiBr}-\mathrm{H}_{2} \mathrm{O} \mathrm{AbCH}$ through a thermal store.
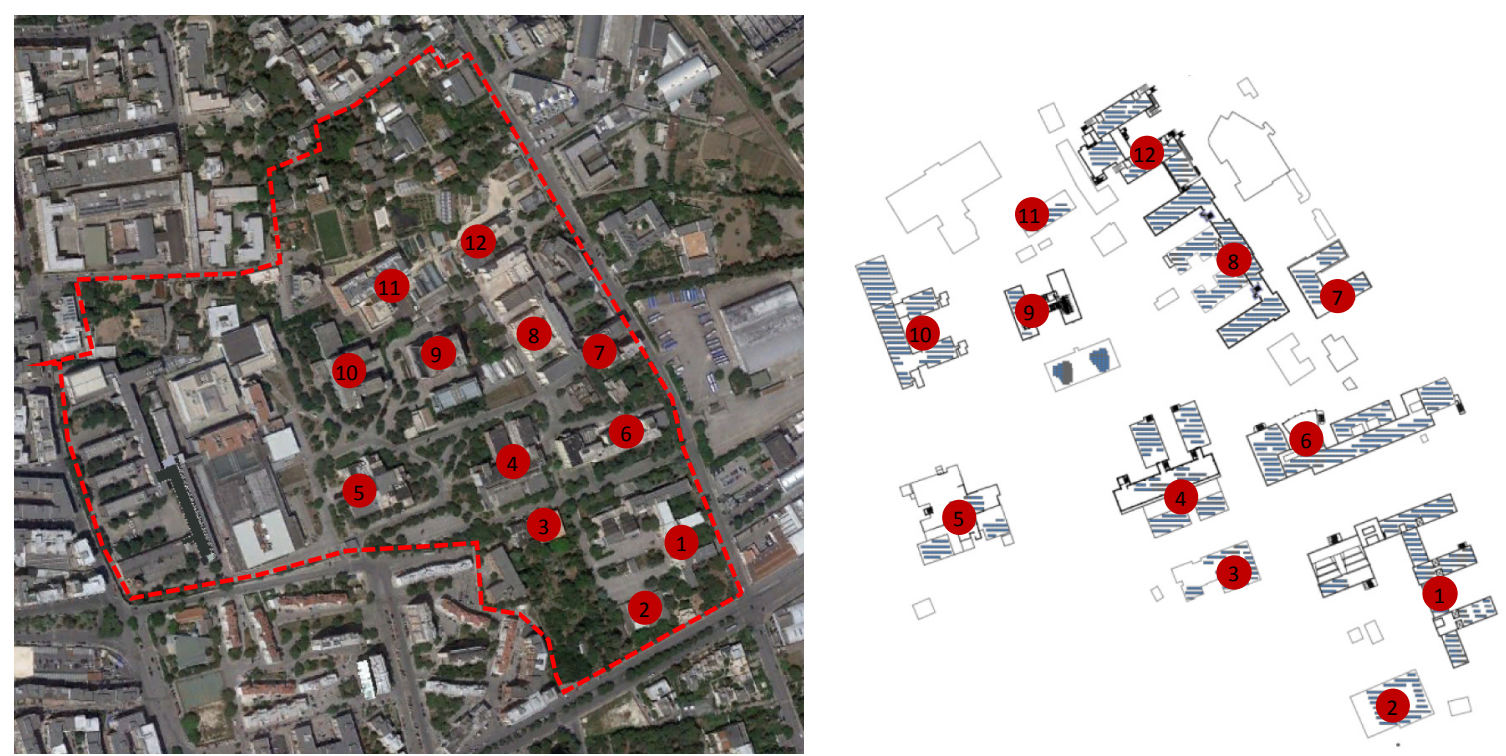

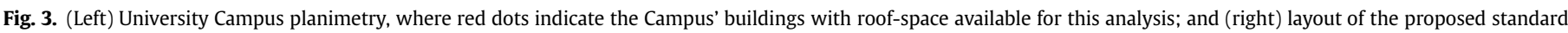
PV system, where striped-blue areas indicate roof areas covered by the proposed PV system.

collectors.

In cooling mode, a single-effect $\mathrm{LiBr}-\mathrm{H}_{2} \mathrm{O} \mathrm{AbCH}$ unit is fed by the thermal output of the PVT collectors (through the backup gas-fired boilers when required) in order to provide cooling (see Fig. 2). The electrical output of the PVT collectors is used to match the Campus's annual electricity demand.

\subsubsection{PVT collector}

Polycarbonate flat-box PVT collectors proposed by the authors are used in this work, in which the heat transfer from the absorber to the fluid is improved by means of $3 \times 2 \mathrm{~mm}$ channels [23]. The PVT collectors are implemented in a transient model developed in TRNSYS with the modified Type 560 [14] to match the thermal performance $\left(\eta_{\text {th }}\right)$ curve shown in Eqs. (1) and (2). The PVT collector has a nominal electrical power of $240 \mathrm{~W}_{\mathrm{p}}$ and an aperture area $\left(A_{\mathrm{c}}\right)$ of $1.55 \mathrm{~m}^{2}$. The nominal electrical efficiency $\left(\eta_{\mathrm{el}}\right)$ of the PVT collector is $14.7 \%$, and the temperature coefficient of the PV cells is $0.45 \% / K$ [23],

$\eta_{\text {th }}=\frac{q_{\mathrm{u}}}{I_{\text {tot }}}=0.726-3.325 \cdot T_{\mathrm{r}}-0.0176 \cdot I_{\text {tot }} \cdot T_{r}^{2}$,
$T_{\mathrm{r}}=\frac{T_{\mathrm{fm}}-T_{\mathrm{a}}}{I_{\text {tot }}}$

where $I_{\text {tot }}\left(\mathrm{W} / \mathrm{m}^{2}\right)$ is the total global solar irradiance on the surface at a tilted angle, $T_{\mathrm{fm}}$ is the mean fluid temperature, $T_{\mathrm{a}}$ is the ambient temperature and $T_{\mathrm{r}}$ is the reduced temperature.

\subsubsection{Stratified water storage tank}

The tank is modelled using 6 fully mixed equal-volume segments that divide the cylinder along its vertical axis (Type 534). The total mass of fluid in the tank is assumed constant. For the stratification, a temperature gradient is preserved in the tank by ensuring that preheated water for $\mathrm{SH}$ demand is supplied via a port at the top of the tank (at node $n=1$ ), and returns at a lower temperature at the middle $(n=4)$. The currently available gas-fired auxiliary heaters (nominal efficiency of $82 \%$ ) are used to heat the water up to the delivery temperature for $\mathrm{SH}\left(80^{\circ} \mathrm{C}\right)$. An immersed heat exchanger connected to the PVT collector runs from the top $(n=1)$ to the bottom $(n=6)$ of the tank to heat the water inside the tank (see Fig. 2). To satisfy the cooling demand, the $\mathrm{AbCH}$ generator is connected to a second port leaving the tank at the top $(n=1)$ and entering at the bottom node $(n=6)$.

The storage tank volume is varied by changing the value of the 
ratio $V_{\mathrm{t}} / A_{\mathrm{cT}}$, where $V_{\mathrm{t}}$ is the tank volume in litres and $A_{\mathrm{CT}}$ is the total PVT collector area in each parallel system in square meters. The size of the solar immersed heat exchanger coil also varies with the tank size, through the variation of the tank height, such that the ratio between the coil heat transfer area, and the total PVT collector area, is not lower than 0.15 [47] to ensure adequate heat transfer. More details of the stratified water storage tank model can be found in previous work [37].

\subsubsection{Absorption chiller}

Considering that the cooling demand of the Campus is met by 45 absorption chillers running in parallel, the commercial WFC-SC-20 $\mathrm{AbCH}$ unit by MAYA [39] is selected with a cooling capacity of $70 \mathrm{~kW}$ and a nominal COP of 0.70 . The performance data of this commercial $\mathrm{AbCH}$ (i.e. the variation of the cooling capacity factor and heat input factor with hot water temperature and cooling water temperature) is considered in Type $107 \mathrm{AbCH}$ model, of which the data file is modified accordingly.

The $\mathrm{AbCH}$ generator is connected with the top of the storage tank through the currently available gas-fired auxiliary heaters to ensure that the water enters the $\mathrm{AbCH}$ at $72.5^{\circ} \mathrm{C}$ at least $\left(70^{\circ} \mathrm{C}\right.$ is the minimum temperature to start the cycle). Chilled water is provided at $7{ }^{\circ} \mathrm{C}$ and returns at $12.5^{\circ} \mathrm{C}$. The nominal cooling water flow-rate of the $\mathrm{AbCH}$ is used, along with an inlet cooling water temperature of $27^{\circ} \mathrm{C}$. At each time step, the heat rejection is estimated by considering the above parameters along with the outlet cooling water temperature. The cooling tower capacity is calculated from the maximum heat rejection at any time step $(140 \mathrm{~kW})$. The electricity consumption of the $\mathrm{AbCH}$ specified in the manufacturer's technical data [39] is extracted from the electricity generated by the PVT collectors.

\subsection{Alternative ETC-based solar heating and cooling system}

An SHC system based on direct-flow ETCs is proposed as an alternative to the PVT-based S-CCHP system for the provision of heating and cooling. An equivalent system to Fig. 2 is proposed but, in this case, the PVT collectors are replaced by ETCs, and there is no electricity generation. The same $\mathrm{AbCH}$ and stratified water storage tank as for the S-CCHP system are used. For the ETCs, the commercially available Thermomax DF400 is selected [44], as it has higher optical efficiency and lower heat loss coefficients than the proposed PVT collectors (see Eq. (3)). The selected ETC has an absorber area of $2 \mathrm{~m}^{2}$, an aperture area of $2.16 \mathrm{~m}^{2}$ and the nominal flow-rate is used $(120 \mathrm{~L} / \mathrm{h})$. The performance data of the ETC provided by the manufacturer is implemented in Type 71 in TRNSYS.

$\eta_{\mathrm{th}}=\frac{q_{\mathrm{u}}}{I_{\text {tot }}}=0.768-1.36 \cdot T_{\mathrm{r}}-0.0053 \cdot I_{t o t} \cdot T_{r}^{2}$,

\subsection{Alternative PV system}

The PV system consists of a set of modules tilted at $30^{\circ}$ and $10^{\circ}$, according to the available possibilities for building integration, with an aperture area of $1.44 \mathrm{~m}^{2}$ and PV modules whose technical specifications are reported in Table 1. Assuming adequate distances between PV modules to maximise yield, it is estimated that a unitary area of $14 \mathrm{~m}^{2} / \mathrm{kW}$ would be required, thus the maximum installed power of the PV system is $1.68 \mathrm{MW}_{\mathrm{p}}$ (total available roofspace of $23,600 \mathrm{~m}^{2}$ ).

The planimetry of the University Campus and the layout of the PV system are reported in Fig. 3. The figure on the right shows the roof areas covered by the proposed PV system (striped-blue areas).
Table 1

Technical specifications of the PV system.

\begin{tabular}{ll}
\hline Parameter & Value \\
\hline Max. voltage & $1000 \mathrm{~V}_{\mathrm{DC}}$ \\
Max. power & $275 \mathrm{~W}_{\mathrm{p}}$ \\
Voltage at nominal power & $31.7 \mathrm{~V}$ \\
Current at nominal power & $8.69 \mathrm{~A}$ \\
Open circuit Voltage $\left(V_{\mathrm{OC}}\right)$ & $38.7 \mathrm{~V}$ \\
Open circuit current $\left(I_{\mathrm{SC}}\right)$ & $9.17 \mathrm{~A}$ \\
Nominal electrical efficiency $\left(\eta_{\mathrm{el}}\right)$ & $16.9 \%$ \\
Temperature coefficients & $V_{\mathrm{OC}}: 0.31 \% /{ }^{\circ} \mathrm{C} ; I_{\mathrm{SC}}: 0.06 \% /{ }^{\circ} \mathrm{C}$ \\
Efficiency losses & $<0.7 \% /$ year \\
\hline
\end{tabular}

According to the Italian legislation, the integration of the PV modules on the building's roof is required to facilitate the permitting procedures and, on the other side, it is the only option due to the scarcity of ground area for PV modules. The location of the PV modules on top of each building also requires a distributed type of installation with $11 \mathrm{DC} / \mathrm{AC}$ inverters which connect the PV generators to the internal electricity network. This slightly increases the investment and maintenance costs and it has been included in the cost figures considered in the economic analysis.

\subsection{Economic analysis}

The investment costs $\left(C_{0}\right)$ of all proposed solar systems have been estimated from price lists available from solar retailers in the EU [48-50]. As shown in Fig. 4, the main costs of the system are associated with the PVT collectors (43\%) [23] or ETC collectors (38\%) [44,51], storage tank (9-10\%) [52] and absorption chiller (18-21\%) [6]. The cost of the storage tank is estimated using a correlation based on market prices of existing tanks across a range of storage volumes [37,38]. The total installation costs are also considered [11]. The auxiliary heater price is not considered as the University Campus, which forms the present case study, already has gas-fired boilers available.

The system's payback time (PBT) is defined as the period of time required to recover the investment of the $\mathrm{S}-\mathrm{CCHP}$ system, and it can be calculated as follows [37,53],

$P B T=\frac{\ln \left[\frac{C_{0} \cdot\left(i_{\mathrm{F}}-d\right)}{C S_{\mathrm{S}-\mathrm{CCHP}}}+1\right]}{\ln \left[\frac{1+i_{\mathrm{F}}}{1+d}\right]}$

where $d$ is the discount rate $(5 \%)[54,55]$ and $i_{\mathrm{F}}$ refers to the fuel inflation rate (3.5\%) considered for the annual cost savings, $C S_{\mathrm{S}-\mathrm{CCHP}}$ [56]. In turn, the annual cost savings $\left(C S_{\mathrm{S}-\mathrm{CCHP}}\right)$ are estimated by accounting for the total electricity and natural gas fuel savings due to the electricity and thermal ( $\mathrm{SH}$ and cooling) energy demand covered by the S-CCHP system, along with the O\&M costs of the system $\left(C_{O \& M}\right)$, and the income for the electricity exported to the grid, as follows [37],

$\mathrm{CS}_{\mathrm{S}-\mathrm{CCHP}}=E_{\mathrm{Cov}} \cdot c_{\mathrm{e}}+\frac{Q_{\mathrm{Cov}}}{\eta_{\mathrm{boil}}} \cdot c_{\mathrm{ng}}+E_{\text {grid }} \cdot F I T-C_{\mathrm{O} \& \mathrm{M}}$

where $E_{\operatorname{Cov}}$ and $Q_{\operatorname{Cov}}$ are the electricity and SH demand covered, $E_{\text {grid }}$ is the electricity exported to the grid, $c_{\mathrm{e}}$ is the component of the electricity price that is avoided/saved by the onsite generation and consumption $(0.145 € / \mathrm{kWh}), c_{\mathrm{ng}}$ is the natural gas price $(0.098$ $€ / \mathrm{kWh}$ ) and FIT is the current feed-in tariff applicable to the excess electricity fed into the grid with the net metering option [42] 0.073 $€ / \mathrm{kWh}$ ). These values correspond to the current tariffs for the University Campus of Bari. It should be noted that the University Campus has a 15-years heating service contract with the local 

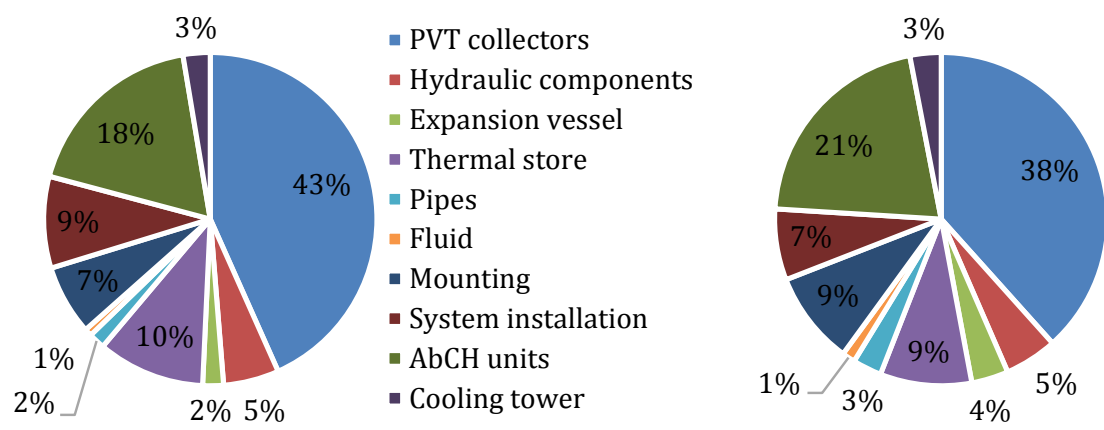

- ETC collectors

- Hydraulic components

- Expansion vessel

- Thermal store

- Pipes

- Fluid

- Mounting

- System installation

- AbCH units

- Cooling tower

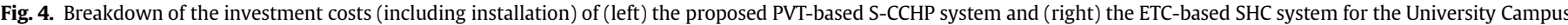
of Bari. Details of these configurations (e.g. total solar field area and total investment cost) are shown in Table 2.

energy provider for the natural gas supply, maintenance of boilers and related distribution system, and for the repowering of inefficient and old boilers. This results in a unitary heating service cost which also includes the depreciation of investment costs incurred by the ESCO and system's maintenance. In particular, the global service contract does not allow a reduction of the demand (or likewise a reduction of the gas consumption with the proposed solar systems) of more than $20 \%$ relative to reference values without incurring penalties. The cooling demand is currently satisfied by electricity-driven HVAC units in the University Campus, so the associated energy savings by the S-CCHP system are included in the electricity term in the economic analyses.

The O\&M costs amount to $1 \%$ of the total equipment costs for the PVT-based S-CCHP system, 0.6\% for the ETC-based SHC system, and $150 € / \mathrm{MW}_{\mathrm{p}}$ for the PV system [57]. The PV and ETC-based SHC system $P B T$ s are estimated using the same equations, considering their investments and cost savings.

\section{Results and discussion}

\subsection{Transient PVT-based combined cooling, heating and power system results}

This section presents detailed results obtained in TRNSYS on an hourly basis with the aim of understanding the operation and performance of the proposed PVT-based S-CCHP system. Nine representative days from Saturday to the following Sunday are selected in this analysis to assess the influence of the weekend (when there is no SH or cooling demands) on the system's performance. Figs. 5 and 6 show the results from the $4^{\text {th }}$ to the $12^{\text {th }}$ of
February.

It is observed that the SH and electricity demands (purple lines with diamonds) are much higher than the thermal and electrical energy generated by the S-CCHP system, so only a limited amount of the Campus energy demands is expected to be covered, due to the limitation of the available roof-space discussed before. The results show that in days with high irradiance levels (dasheddotted yellow line with triangles in Fig. 5), more electricity and SH demand are covered (dashed blue lines with squares). Fig. 5 shows that in the particular week considered here, all the electricity generated by the system (red lines with circles) is directly consumed onsite $\left(E_{\mathrm{S}-\mathrm{CCHP}}=E_{\mathrm{Cov}}\right)$.

Fig. 6 shows that the temperature at the top of the hot-water storage tank (dotted lines with triangles) increases considerably during the weekends (first two and last two days shown in this plot) as there is no $\mathrm{SH}$ demand, so no water is extracted from the storage tank. This allows covering a higher amount of SH demand on the following Monday.

Figs. 7 and 8 show results from the $15^{\text {th }}$ to the $23^{\text {rd }}$ of July. Similar electricity results than for the winter week (Fig. 5) are obtained, with all the electricity generated directly consumed onsite. From these figures, it is observed that, similar to the winter operation, the temperature at the top of the tank (dotted lines with triangles) increases considerably during the weekends (first two and last two days) reaching almost $90^{\circ} \mathrm{C}$ (see Fig. 8), as there is no cooling demand, so no water is extracted from the storage tank. This enables a situation, on the following Monday, wherein the temperature reached at the top of the tank is high enough to run the $\mathrm{AbCH}$, so all the cooling demand can be satisfied until the end of the day (blue lines with squares), when some auxiliary heat is

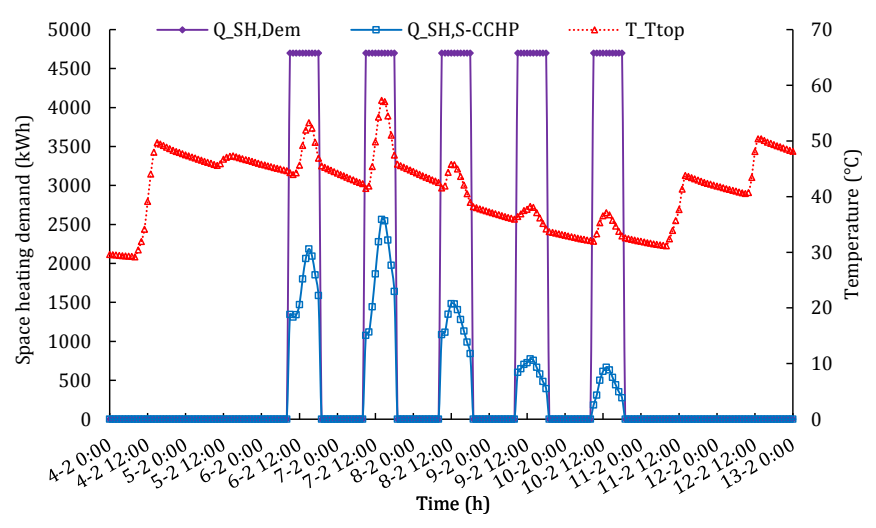

Fig. 6. Total SH demand ( $\left.Q_{S H, D e m}\right)$, SH demand covered $\left(Q_{S H, S-C C H P}\right)$, and water temperature at the top of the storage tank $\left(T_{\mathrm{Ttop}}\right)$ for the S-CCHP system during 4-12 February.
Fig. 5. Electricity generated ( $\left.E_{\mathrm{S}-\mathrm{CCHP}}\right)$, electrical demand covered ( $\left.E_{\mathrm{Cov}}\right)$, electrical demand $\left(E_{\text {Dem }}\right)$ and total solar irradiance at a tilted angle $\left(I_{\text {tot }}\right)$ for the S-CCHP system during 4-12 February.

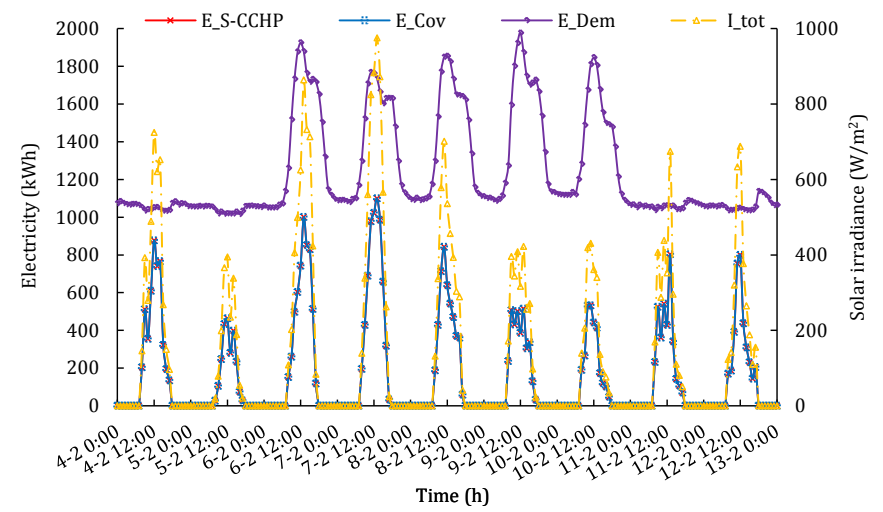




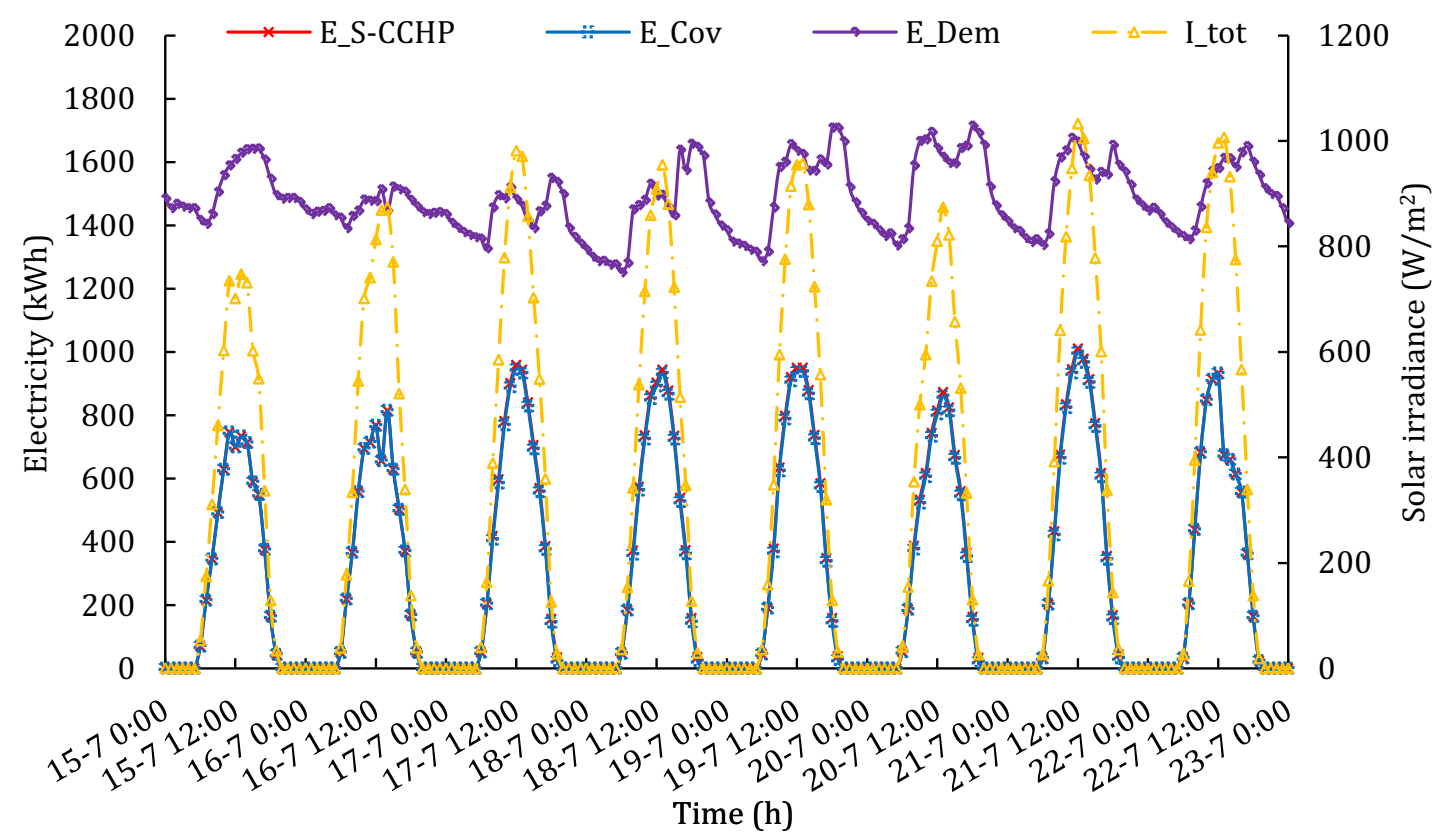

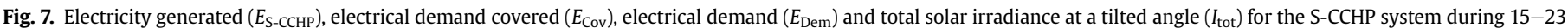
July.

needed (yellow line with crosses) to increase the temperature of the water entering the $\mathrm{AbCH}$ to $72.5^{\circ} \mathrm{C}$ (dashed-dotted green line with pluses), required to run the unit.

Conversely, in the rest of the days, more auxiliary heat is needed, specially at the beginning and end of the day. Here, it should be highlighted that the improved thermal performance of the PVT collectors in summer, especially during the main hours of the day (12-5 p.m.), due to higher solar irradiance levels, matches the higher hot water requirements of the $\mathrm{AbCH}$ owing to higher cooling demand at those periods. Therefore, there is a double benefit: on the one hand, hot water from the top of the tank is extracted to run the $\mathrm{AbCH}$, avoiding overheating problems, and on the other, the water returning to the tank is at a lower temperature which maintains the bottom of the tank at a lower temperature, thus lowering also the temperature of the water entering the PVT collectors.

\subsection{Technoeconomic assessment}

In this section, the annual technoeconomic results of the proposed PVT-based S-CCHP system are compared with two solar alternatives: i) ETC-based SHC system for the provision of heating

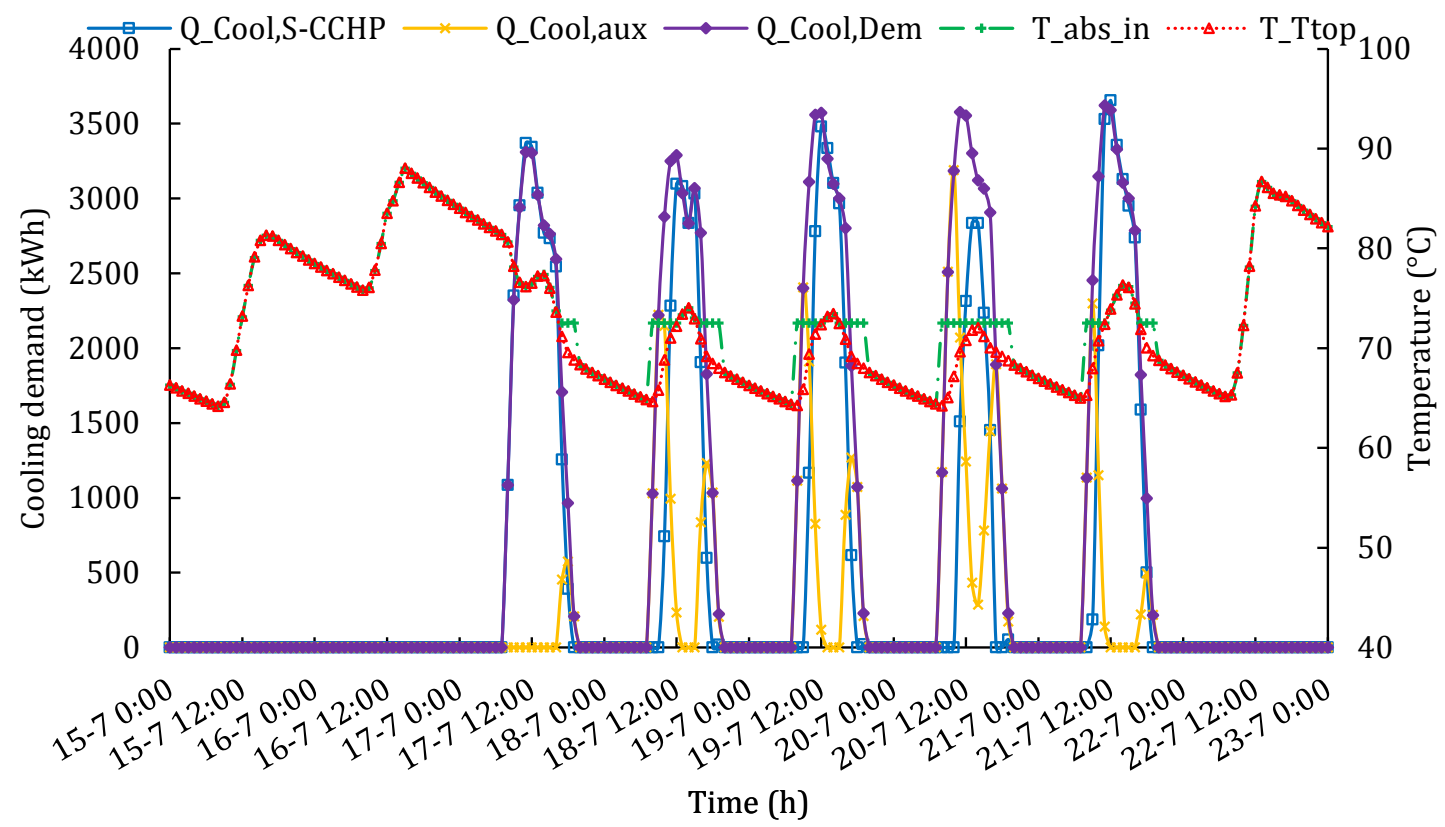

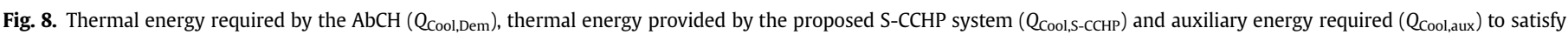
the cooling demand for the S-CCHP system during 15-23 July. 
and cooling (Section 3.2.1); and ii) a standard PV system to provide the electricity demand of the Campus (including the electricity required to run the current HVAC system for air-conditioning) (Section 3.2.2).

\subsubsection{Comparison of the PVT-based S-CCHP with an ETC-based SHC system}

Table 2 shows annual performance and economic results for the proposed PVT-based S-CCHP system and for the equivalent ETCbased SHC system. It is observed that the ETC-based SHC system covers a higher percentage of the $\mathrm{SH}(27.7 \%$ vs. $20.9 \%)$ and cooling (74.2\% vs. 55.1\%) demands. However, the annual $\mathrm{CO}_{2}$ emission reduction and primary energy savings achieved by the PVT-based S-CCHP system are considerable higher (911 vs. 386 tons $\mathrm{CO}_{2} /$

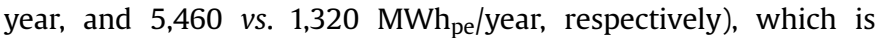
attributed to the electricity generation by the S-CCHP system since the electrical output accounts for $68 \%$ of the total $\mathrm{CO}_{2}$ emission reduction, and $71 \%$ of the primary energy savings. Here it should be noted that only the $\mathrm{CO}_{2}$ emissions associated with the system's operation are considered in the present work. Given the indicated promise of this technology in terms of its potential environmental benefits, a complete environmental impact assessment in the form of life cycle analyses appears useful, which is proposed as an avenue for further work.

Despite the lower investment cost of the ETC-based SHC system (13\% lower), its PBT is considerably (2.3 times) higher than the SCCHP system, which is again due to the electricity demand covered by the S-CCHP system (and, at lesser extent, excess electricity sold to the grid), which accounts for $66 \%$ of the total cost savings. The reason is the higher (1.5 times) price of electricity than natural gas (see Table 2). As a consequence, it can be concluded that in this particular case where there are simultaneous $\mathrm{SH} /$ cooling and electricity demands, a system capable of simultaneously generating electrical and thermal energy such as the proposed S-CCHP system appears as a more suitable alternative than an SHC system.

In order to understand the influence of utility (electricity, natural gas) prices on the systems' economics, two additional scenarios are assessed: i) the current national utility prices in Italy where the University Campus is located; and ii) the current national utility prices in Denmark, which has the highest combined rates $\left(c_{n g}+c_{\mathrm{e}}\right)$ in the EU [58]. The results show that the costcompetitiveness of the analysed solar systems is very sensitive to the utility prices. In the case of the SHC system, Table 2 shows that the natural gas price should be considerably higher for this system to become an interesting alternative. In turn, it is observed that the proposed S-CCHP system has a PBT below the system's lifetime ( 25 years) $[59,60]$ when considering the current utility prices applicable to the University Campus (16.7 years), so the system is expected to generate profits during the last $\sim 8$ years of its life. It is also observed that the S-CCHP system emerges as a promising decarbonisation solution if utility prices increase, which is likely to occur given recent trends [38]. Specifically, if utility prices in Italy approach those currently in Denmark, the PBT more than halves to 10.2 years.

\subsubsection{Comparison of the PVT-based S-CCHP system with a PV system}

Table 3 shows the annual performance and economic results for the proposed PVT-based S-CCHP system with three different sizes, as well as for the equivalent PV system. With the S-CCHP system presented in Section 3.1 (same installed power as the PV system, $1.68 \mathrm{MW}_{\mathrm{p}}$ ) it is possible to cover $20.9 \%$ of $\mathrm{SH}, 55.1 \%$ of cooling and $16.3 \%$ of electricity demands of the University Campus of Bari. It should be noted that the percentage of onsite electricity consumption is very high ( $>99 \%$ of the electricity generated by the PVT collectors is directly consumed), and the surplus electricity at any time step is exported to the grid with the feed in tariff FIT reported in Eq. (5).

In the PV system, 7.7\% of the electricity generated is fed into the grid and the electricity demand covered increases up to $20.7 \%$. However, this influences the profitability of the investment, because the current avoided cost from onsite generation $(0.145$ $€ / \mathrm{kWh})$ is applied to the electricity generated and consumed onsite, while a lower tariff (a FIT of $0.073 € / \mathrm{kWh}$ ) is applied to the excess electricity exported to the grid with the net metering option. As discussed before, the limited amount of energy demand coverage is due to the restraint roof-space availability in the buildings.

The PVT-based system $P B T$ is 16.7 years, which is considerable longer (2.7 times) than the PBT of the equivalent PV system (6.1 years). This is attributed to the much higher investment cost of the S-CCHP system. Another handicap that hinders the potential of the proposed S-CCHP system is the lower price of natural gas than the electricity price. If the natural gas price was the same ( $c_{\mathrm{ng}}=c_{\mathrm{e}}=0.145 € / \mathrm{kWh}$ ), the S-CCHP system's PBT would decrease to 14.6 years. An incentive of the proposed S-CCHP system is high potential $\mathrm{CO}_{2}$ emission reduction and primary energy savings (911 tons $\mathrm{CO}_{2}$ /year and $5460 \mathrm{MWh}_{\text {pe}} /$ year), which are $16 \%$ and $12 \%$ higher than for the PV system. As noted above, a complete lifecycle analysis is proposed as further work to evaluate the full environmental impact of these solar alternatives from cradle-to-grave.

For comparison purposes, two additional S-CCHP system sizes were analysed: i) a system with the same installed area as the PV system $\left(8,830 \mathrm{~m}^{2}, 1.37 \mathrm{MW}_{\mathrm{p}}\right)$; and ii) assuming that half of the available roof-space is covered by PVT collectors $\left(11,800 \mathrm{~m}^{2}, 1.84\right.$ $\mathrm{MW}_{\mathrm{p}}$ ). Table 3 shows that in the former case, the lower amount of energy demand covered due to the lower PVT collectors installed area leads to a higher $P B T$ and a lower $\mathrm{CO}_{2}$ emission reduction.

Table 2

Energetic and economic results of a PVT-based S-CCHP system and an ETC-based SHC system for different utility-price scenarios.

\begin{tabular}{|c|c|c|c|c|c|c|}
\hline \multirow[t]{2}{*}{ Utility prices } & \multicolumn{3}{|c|}{ PVT-based S-CCHP system } & \multicolumn{3}{|c|}{ ETC-based SHC system } \\
\hline & Current prices & National prices & Danish prices & Current prices & National prices & Danish prices \\
\hline Installed area $\left(\mathrm{m}^{2}\right)$ & 10,850 & 10,850 & 10,850 & 10,850 & 10,850 & 10,850 \\
\hline Total investment $\left(C_{0}, M €\right)$ & 4.88 & 4.88 & 4.88 & 4.24 & 4.24 & 4.24 \\
\hline SH demand covered $(\%)$ & 20.9 & 20.9 & 20.9 & 27.7 & 27.7 & 27.7 \\
\hline Cooling demand covered (\%) & 55.1 & 55.1 & 55.1 & 74.2 & 74.2 & 74.2 \\
\hline Electricity demand covered (\%) & 16.3 & 16.3 & 16.3 & - & - & - \\
\hline Annual $\mathrm{CO}_{2}$ emission reduction (tons $\mathrm{CO}_{2} /$ year) & 911 & 911 & 911 & 386 & 386 & 386 \\
\hline Primary energy savings (MWh $\mathrm{he}_{\mathrm{pe}} /$ year) & 5,460 & 5,460 & 5,460 & 1,320 & 1,320 & 1,320 \\
\hline Natural gas price $\left(c_{\mathrm{ng}}, € / \mathrm{kWh}\right)$ & 0.098 & 0.032 & 0.071 & 0.098 & 0.032 & 0.071 \\
\hline Electricity price $\left(c_{\mathrm{e}}, € / \mathrm{kWh}\right)$ & 0.145 & 0.133 & 0.252 & 0.145 & 0.133 & 0.252 \\
\hline Payback time (PBT, years) & 16.7 & 23.2 & 10.2 & 37.8 & $>100$ & 35.8 \\
\hline
\end{tabular}


Table 3

Energetic and economic results of different-sized PVT-based S-CCHP and PV-only systems.

\begin{tabular}{|c|c|c|c|c|}
\hline & \multicolumn{3}{|c|}{ S-CCHP system } & \multirow{2}{*}{$\frac{\text { PV system }}{1.68}$} \\
\hline Installed power $\left(\mathrm{MW}_{\mathrm{p}}\right)$ & 1.68 & 1.37 & 1.84 & \\
\hline Installed area $\left(\mathrm{m}^{2}\right)$ & 10,850 & 8,830 & 11,800 & 8,830 \\
\hline Total investment $\left(C_{0}, \mathrm{M} €\right)$ & 4.88 & 4.17 & 5.22 & 1.60 \\
\hline SH demand covered $(\%)$ & 20.9 & 17.8 & 22.4 & - \\
\hline Cooling demand covered (\%) & 55.1 & 45.9 & 58.8 & - \\
\hline Electricity demand covered (\%) & 16.3 & 13.3 & 17.7 & 19.1 \\
\hline Payback time (PBT, years) & 16.7 & 17.5 & 16.5 & 6.1 \\
\hline Annual $\mathrm{CO}_{2}$ emission reduction (tons $\mathrm{CO}_{2} /$ year) & 911 & 752 & 986 & 784 \\
\hline Primary energy savings (MWh $\mathrm{h}_{\mathrm{pe}} /$ year $)$ & 5,460 & 4,500 & 5,910 & 4,880 \\
\hline
\end{tabular}

Conversely, the results show that if more PVT collectors are installed, the higher energy demand covered compensates the higher investment cost, obtaining a lower PBT (16.5 years). Therefore, these results confirm that in this case, the limiting factor for the optimum system's sizing is the roof-space availability.

Finally, it is noted that this technoeconomic assessment does not include the subsidies available in the Italian framework for energy saving measures ('White certificates' or 'conto energia termico' in particular). These subsidies would provide a further income for the solar based generation of heating, power and cooling, based on the avoided fossil fuels' consumption, that would increase the investment profitability. However, these were not considered due to the uncertainty on their continuing availability and also in order to make the results more transferable to other countries.

\section{Further discussion and conclusions}

A modelling methodology has been developed and used to examine the technoeconomic performance of solar combined cooling, heating and power (S-CCHP) systems based on PVT collectors. The University Campus of Bari is selected as a case study to demonstrate how the methodology can be used to analyse the suitability and value of the proposed systems when providing space heating ( $\mathrm{SH}$ ), cooling and electricity to the Campus buildings. The hourly energy demand profiles of the Campus have been estimated based on real consumption data provided by Campus managers, and have been used as inputs to the transient S-CCHP model developed in TRNSYS, which features an array of novel hybrid flatbox PVT collectors coupled via a thermal store to a commercial single-effect $\mathrm{LiBr}-\mathrm{H}_{2} \mathrm{O} \mathrm{AbCH}$ unit. The current gas-fired boilers are used as a backup heating system. Three alternative solar systems are analysed and compared based on the following technologies: PV panels with an electrical output only, PVT collectors, and evacuated tube collectors (ETCs) with no electricity generation.

Transient simulations are run over a full year on an hourly basis, for which real performance data for the different system components are implemented (e.g. commercial AbCH and ETC). The investment costs of the solar systems in each case, and current electricity and gas prices are considered for the economic analyses. The hourly results are summed to obtain the annual energy yields and energy demands covered by each system, which are then used to estimate the systems' $P B T, \mathrm{CO}_{2}$ emission reduction potential, and primary energy savings potential.

The results show that, due to the high hot water delivery temperature $\left(80^{\circ} \mathrm{C}\right)$ and the limited roof-space availability, the proposed S-CCHP system only covers $20.9 \%$ of the SH demand of the Campus, when it is used to preheat the water to satisfy the $\mathrm{SH}$ demand. However, the hot water generated by the PVT collectors can be used in summer to run the commercial $\mathrm{AbCH}$ units, with which $55.1 \%$ of cooling demand is covered. Thus, the proposed SCCHP system has the potential to considerably reduce the electricity needs in summer used by the current HVAC systems for air-conditioning. Furthermore, the proposed system covers an additional $16.3 \%$ of the electricity demand. Still, due to the considerably higher investment cost of the S-CCHP system compared to a PV system of the same installed power, the PBT of the former is significantly higher (16.7 years vs. 6.1 years).

Furthermore, an alternative SHC system has also been assessed, in which the PVT collectors have been replaced by evacuated tube collectors (ETCs), for the provision of heating and cooling to the University Campus, but without electricity generation. The results show that, in this case, the no generation of electricity limits the profitability of the ETC-based SHC system, which has 2.3 times longer PBT than the S-CCHP system. Therefore, it can be concluded that the lower price of natural gas compared to the electricity price hinders the potential of the solar thermal solutions when these systems are proposed to substitute current gas-fired boilers.

In order to understand the influence of utility prices on the economics of S-CCHP/SHC systems, two scenarios with current national utility prices of two countries are assessed: Italy, where the study is based, and Denmark, which was selected as it is the EU country with the highest combined utility prices. The results show that the cost-competitiveness of the solar systems considered here is very sensitive to these prices and that the proposed S-CCHP systems could become a promising decarbonisation solution, achieving a $P B T$ of 10.2 years, if utility prices increase, which is likely to occur given recent trends.

In terms of the systems' potential for $\mathrm{CO}_{2}$ emission reductions and primary energy savings, the results show that the PVT-based SCCHP system has the potential to displace around 911 tons of $\mathrm{CO}_{2}$ and to save around 5,460 $\mathrm{MWh}_{\mathrm{pe}}$ of primary energy per year. By comparison, these values are $16 \%$ and $12 \%$ greater than those associated with the equivalent PV system, and 1.4 times and 3 times greater than those associated with the ETC-based SHC system. This promising environmental performance suggests that a useful avenue for further work involves complete environmental impact assessments through lifecycle analyses, which can provide a more holistic picture of the benefits of the proposed PVT-based S-CCHP system and any alternatives.

This work suggests that PVT-based S-CCHP systems have an important potential to decarbonise urban areas, in particular where space is at a premium since both electrical and thermal outputs are generated from the same area. Additional research on solar heating and cooling technologies is required to enhance efficiency and reduce investment costs, in order to make these solutions costcompetitive with other mature renewable energy alternatives such as commercial PV panels.

\section{Acknowledgements}

This paper is an extension of work presented at the 13th Conference of Sustainable Development of Energy Water and 
Environment System (SDEWES) in Palermo from 30 September to 4 October 2018. This work was supported by the UK Engineering and Physical Sciences Research Council (EPSRC) [grant number EP/ M025012/1]. Supporting data can be obtained from cep-lab@ imperial.ac.uk.

\section{References}

[1] M. Alobaid, B. Hughes, J. Kaiser, D.O. Connor, A. Heyes, A review of solar driven absorption cooling with photovoltaic thermal systems, Renew. Sustain. Energy Rev. 76 (2017) 728-742, https://doi.org/10.1016/j.rser.2017.03.081.

[2] N. Fumo, V. Bortone, J.C. Zambrano, Comparative analysis of solar thermal cooling and solar photovoltaic cooling systems, J. Sol. Energy Eng. 135 (2012) 21002-21006

[3] C.N. Markides, Low-concentration solar-power systems based on organic rankine cycles for distributed-scale applications: Overview and further developments, Front. Energy Res. 3 (2015), https://doi.org/10.3389/ fenrg.2015.00047, 473389-47.

[4] European Commission, The Energy-Efficient Buildings PPP: Research for Low Energy Consumption Buildings in the EU, 2013.

[5] European Commission, Energy: Heating and Cooling, 2018. https://ec.europa. eu/energy/en/topics/energy-efficiency/heating-and-cooling. (Accessed 23 November 2018)

[6] A. Buonomano, F. Calise, A. Palombo, Solar heating and cooling systems by absorption and adsorption chillers driven by stationary and concentrating photovoltaic/thermal solar collectors: Modelling and simulation, Renew. Sustain. Energy Rev. 82 (2018) 1874-1908, https://doi.org/10.1016/ j.rser.2017.10.059.

[7] J. Freeman, K. Hellgardt, C.N. Markides, An assessment of solar-powered organic Rankine cycle systems for combined heating and power in UK domestic applications, Appl. Energy 138 (2015) 605-620, https://doi.org/ 10.1016/J.APENERGY.2014.10.035.

[8] J. Freeman, I. Guarracino, S.A. Kalogirou, C.N. Markides, A small-scale solar organic Rankine cycle combined heat and power system with integrated thermal energy storage, Appl. Therm. Eng. 127 (2017) 1543-1554, https:// doi.org/10.1016/J.APPLTHERMALENG.2017.07.163.

[9] K.F. Fong, C.K. Lee, T.T. Chow, Comparative study of solar cooling systems with building-integrated solar collectors for use in sub-tropical regions like Hong Kong, Appl. Energy 90 (2012) 189-195, https://doi.org/10.1016/ J.APENERGY.2011.06.013.

[10] R. Thygesen, B. Karlsson, Simulation and analysis of a solar assisted heat pump system with two different storage types for high levels of PV electricity selfconsumption, Sol. Energy 103 (2014) 19-27, https://doi.org/10.1016/ j.solener.2014.02.013.

[11] M. Herrando, C.N. Markides, K. Hellgardt, A UK-based assessment of hybrid PV and solar-thermal systems for domestic heating and power: System performance, Appl. Energy 122 (2014) 288-309, https://doi.org/10.1016/ j.apenergy.2014.01.061.

[12] A. Ramos, M.A. Chatzopoulou, I. Guarracino, J. Freeman, C.N. Markides, Hybrid photovoltaic-thermal solar systems for combined heating, cooling and power provision in the urban environment, Energy Convers. Manag. 150 (2017) 838-850, https://doi.org/10.1016/j.enconman.2017.03.024.

[13] I. Guarracino, A. Mellor, N.J. Ekins-Daukes, C.N. Markides, Dynamic coupled thermal-and-electrical modelling of sheet-and-tube hybrid photovoltaic/ thermal (PVT) collectors, Appl. Therm. Eng. 101 (2016) 778-795, https:// doi.org/10.1016/j.applthermaleng.2016.02.056.

[14] M. Herrando, A. Ramos, I. Zabalza, C.N. Markides, Energy performance of a solar trigeneration system based on a novel hybrid PVT panel for residential applications, in: ISES Solar World Congress 2017 - IEA SHC International Conference on Solar Heating and Cooling for Buildings and Industry 2017, Proceedings, Abu Dhabi (UAE), 2017, pp. 1090-1101.

[15] F. Calise, Thermoeconomic analysis and optimization of high efficiency solar heating and cooling systems for different Italian school buildings and climates, Energy Build. 42 (2010) 992-1003, https://doi.org/10.1016/ j.enbuild.2010.01.011.

[16] F. Assilzadeh, S.A. Kalogirou, Y. Ali, K. Sopian, Simulation and optimization of a LiBr solar absorption cooling system with evacuated tube collectors, Renew. Energy 30 (2005) 1143-1159, https://doi.org/10.1016/J.RENENE.2004.09.017.

[17] D. Neyer, M. Ostheimer, N. Hauer, C. Halmdienst, W. Pink, Application of an adapted single-/half- effect NH3/H2O absorption chiller in tri-generation and solar cooling systems, Sol. Energy 173 (2018) 715-727, https://doi.org/ 10.1016/J.SOLENER.2018.08.010.

[18] E. Bellos, C. Tzivanidis, Performance analysis and optimization of an absorption chiller driven by nanofluid based solar flat plate collector, J. Clean. Prod. 174 (2018) 256-272, https://doi.org/10.1016/J.JCLEPRO.2017.10.313.

[19] A. Baghernejad, M. Yaghoubi, K. Jafarpur, Exergoeconomic optimization and environmental analysis of a novel solar-trigeneration system for heating, cooling and power production purpose, Sol. Energy 134 (2016) 165-179, https://doi.org/10.1016/J.SOLENER.2016.04.046.

[20] M.J. Tierney, Options for solar-assisted refrigeration-trough collectors and double-effect chillers, Renew. Energy 32 (2007) 183-199, https://doi.org/ 10.1016/J.RENENE.2006.01.018.
[21] A. Lubis, J. Jeong, K. Saito, N. Giannetti, H. Yabase, M. Idrus Alhamid, et al., Solar-assisted single-double-effect absorption chiller for use in Asian tropical climates, Renew. Energy 99 (2016) 825-835, https://doi.org/10.1016/ J.RENENE.2016.07.055.

[22] A. Shirazi, R.A. Taylor, S.D. White, G.L. Morrison, Transient simulation and parametric study of solar-assisted heating and cooling absorption systems: An energetic, economic and environmental (3E) assessment, Renew. Energy 86 (2016) 955-971, https://doi.org/10.1016/J.RENENE.2015.09.014.

[23] M. Herrando, A. Ramos, I. Zabalza, C.N. Markides, A comprehensive assessment of alternative absorber-exchanger designs for hybrid PVT-water collectors, Appl. Energy 235 (2019) 1583-1602, https://doi.org/10.1016/ J.APENERGY.2018.11.024.

[24] A. Arabkoohsar, G.B. Andresen, A smart combination of a solar assisted absorption chiller and a power productive gas expansion unit for cogeneration of power and cooling, Renew. Energy 115 (2018) 489-500, https://doi.org/ 10.1016/J.RENENE.2017.08.069.

[25] J. Freeman, K. Hellgardt, C.N. Markides, An assessment of solar-thermal collector designs for small-scale combined heating and power applications in the United Kingdom, Heat Transf. Eng. 36 (2015) 1332-1347, https://doi.org/ 10.1080/01457632.2015.995037.

[26] E. Bellos, C. Tzivanidis, Parametric analysis and optimization of a cooling system with ejector-absorption chiller powered by solar parabolic trough collectors, Energy Convers. Manag. 168 (2018) 329-342, https://doi.org/ 10.1016/J.ENCONMAN.2018.05.024.

[27] J. Freeman, K. Hellgardt, C.N. Markides, Working fluid selection and electrical performance optimisation of a domestic solar-ORC combined heat and power system for year-round operation in the UK, Appl. Energy 186 (2017) 291-303. https://doi.org/10.1016/J.APENERGY.2016.04.041.

[28] Y. Hang, M. Qu, R. Winston, L. Jiang, B. Widyolar, H. Poiry, Experimental based energy performance analysis and life cycle assessment for solar absorption cooling system at University of Californian, Merced, Energy Build. 82 (2014) 746-757, https://doi.org/10.1016/J.ENBUILD.2014.07.078.

[29] Z.Y. Xu, R.Z. Wang, Simulation of solar cooling system based on variable effect LiBr-water absorption chiller, Renew. Energy 113 (2017) 907-914, https:// doi.org/10.1016/J.RENENE.2017.06.069.

[30] Z.S. Lu, R.Z. Wang, Z.Z. Xia, X.R. Lu, C.B. Yang, Y.C. Ma, et al., Study of a novel solar adsorption cooling system and a solar absorption cooling system with new CPC collectors, Renew. Energy 50 (2013) 299-306, https://doi.org/ 10.1016/J.RENENE.2012.07.001.

[31] P. Finocchiaro, M. Beccali, B. Nocke, Advanced solar assisted desiccant and evaporative cooling system equipped with wet heat exchangers, Sol. Energy 86 (2012) 608-618, https://doi.org/10.1016/J.SOLENER.2011.11.003.

[32] A. Buonomano, F. Calise, A. Palombo, Solar heating and cooling systems by CPVT and ET solar collectors: A novel transient simulation model, Appl. Energy 103 (2013) 588-606, https://doi.org/10.1016/J.APENERGY.2012.10.023.

[33] F. Calise, M. Dentice d'Accadia, A. Palombo, L. Vanoli, Dynamic simulation of a novel high-temperature solar trigeneration system based on concentrating photovoltaic/thermal collectors, Energy 61 (2013) 72-86, https://doi.org/ 10.1016/j.energy.2012.10.008.

[34] F. Calise, M. Dentice d'Accadia, R.D. Figaj, L. Vanoli, A novel solar-assisted heat pump driven by photovoltaic/thermal collectors: Dynamic simulation and thermoeconomic optimization, Energy 95 (2016) 346-366, https://doi.org/ 10.1016/J.ENERGY.2015.11.071.

[35] F. Calise, R.D. Figaj, L. Vanoli, A novel polygeneration system integrating photovoltaic/thermal collectors, solar assisted heat pump, adsorption chiller and electrical energy storage: Dynamic and energy-economic analysis, Energy Convers. Manag. 149 (2017) 798-814, https://doi.org/10.1016/ J.ENCONMAN.2017.03.027.

[36] M. Herrando, C.N. Markides, Hybrid PV and solar-thermal systems for domestic heat and power provision in the UK: Techno-economic considerations, Appl. Energy 161 (2016) 512-532, https://doi.org/10.1016/ j.apenergy.2015.09.025.

[37] M. Herrando, A. Ramos, J. Freeman, I. Zabalza, C.N. Markides, Technoeconomic modelling and optimisation of solar combined heat and power systems based on flat-box PVT collectors for domestic applications, Energy Convers. Manag. 175 (2018) 67-85, https://doi.org/10.1016/j.enconman.2018.07.045.

[38] M. Herrando, A. Ramos, I. Zabalza, Cost competitiveness of a novel PVT-based solar combined heating and power system: Influence of economic parameters and financial incentives, Energy Convers. Manag. 166 (2018) 758-770, https://doi.org/10.1016/j.enconman.2018.04.005.

[39] MAYA, Water Fired Absorption Chillers WFC Series, 2018. http://www.mayaairconditioning.com/eng/pdf/WFC Series LD_001_EN.pdf. (Accessed 23 November 2018).

[40] S.A. Klein, TRNSYS 17: A Transient System Simulation Program, 2016.

[41] Meteonorm Data Base, Meteonorm Data Base, 2017.

[42] A.M. Pantaleo, J. Fordham, O.A. Oyewunmi, P. De Palma, C.N. Markides, Integrating cogeneration and intermittent waste-heat recovery in food processing: Microturbines vs. ORC systems in the coffee roasting industry, Appl. Energy 225 (2018) 782-796, https://doi.org/10.1016/j.apenergy.2018.04.097.

[43] F. Calise, M. Dentice D'Accadia, L. Vanoli, Design and dynamic simulation of a novel solar trigeneration system based on hybrid photovoltaic/thermal collectors (PVT), Energy Convers. Manag. 60 (2012) 214-225, https://doi.org/ 10.1016/j.enconman.2012.01.025.

[44] Kingspan. Thermomax DF400 Evacuated Tube Collectors, https://www. kingspan.com/gb/en-gb/products/renewable-technologies/solar-thermal/ 
solar-evacuated-tube-collectors/thermomax-df400-evacuated-tube-br-collectors. (Accessed 19 November 2018).

[45] Y. Ding, Q. Zhang, Z. Wang, M. Liu, Q. He, A simplified model of dynamic interior cooling load evaluation for office buildings, Appl. Therm. Eng. 108 (2016) 1190-1199, https://doi.org/10.1016/J.APPLTHERMALENG.2016.07.191.

[46] Y. Ding, Q. Zhang, T. Yuan, F. Yang, Effect of input variables on cooling load prediction accuracy of an office building, Appl. Therm. Eng. 128 (2018) 225-234, https://doi.org/10.1016/J.APPLTHERMALENG.2017.09.007.

[47] IDAE, CENSOLAR, Solar Thermal Energy Installations, Technical Specifications Document of Low Temperature Installations, 2009.

[48] Barilla Solar, Wholesale Solar Thermal Supplies Barilla Solar, 2017. http:// www.barillasolar.co.uk. (Accessed 19 July 2017).

[49] Viridian Solar, The Pod - Solar Water Heating Simplified, 2017. http://www. viridiansolar.co.uk/solar-products-solar-heating-with-combi-pod.html. (Accessed 19 July 2017).

[50] Wagner Renewable, Home Page - Wagner Renewables Ltd., 2017. http:/ www.wagnersolarshop.com. (Accessed 19 July 2017).

[51] M. Nájera-Trejo, I.R. Martin-Domínguez, J.A. Escobedo-Bretado, Economic feasibility of flat plate vs evacuated tube solar collectors in a combisystem, Energy Proc. 91 (2016) 477-485, https://doi.org/10.1016 J.EGYPRO.2016.06.181.

[52] Lapesa, GEISER INOX, 2017. http://www.lapesa.es/en/domestic-hot-water geiser-inox.html. (Accessed 19 September 2017).

[53] S.A. Kalogirou, Solar Energy Engineering: Processes and Systems, second ed. Academic Press, 2014 https://doi.org/10.1016/B978-0-12-374501-9.00014-5.

[54] Y. Kim, K. Thu, H. Kaur, C. Singh, K. Choon, Thermal analysis and performance optimization of a solar hot water plant with economic evaluation, Sol. Energy 86 (2012) 1378-1395, https://doi.org/10.1016/j.solener.2012.01.030.

[55] International Energy Agency (IEA), Projected Costs of Generating Electricity, 2010.

[56] ISTAT, Prezzi Al Consumo - Statistiche Flash, 2018.

[57] N. Hartmann, C. Glueck, F.P. Schmidt, Solar cooling for small office buildings: comparison of solar thermal and photovoltaic options for two different European climates, Renew. Energy 36 (2011) 1329-1338, https://doi.org/ 10.1016/J.RENENE.2010.11.006.

[58] Eurostat, Database - Energy Statistics - Prices, 2017.

[59] International Energy Agency (IEA), Technology Roadmap: Solar Heating and Cooling, 2012.

[60] J. Hansen, H. Sorensen, IEA SHC Task 35 PV/Thermal Solar Systems, 2006

[61] C.N. Markides, The role of pumped and waste heat technologies in a highefficiency sustainable energy future for the UK, Appl. Therm. Eng. 53 (2) (2013) 197-209. https://doi.org/10.1016/j.applthermaleng.2012.02.037.

[62] A. Ramos, I. Guarracino, A. Mellor, D. Alonso-Álvarez, P. Childs, N.J. EkinsDaukes, C.N. Markides, Solar-thermal and hybrid photovoltaic-thermal systems for renewable heating, Imperial College London Grantham Institute, Briefing paper No 22, 2017, https://www.ecopost.info/wp-content/uploads/ 2017/07/Briefing-P-22-Solar-heat_web.pdf.

[63] I. Guarracino, J. Freeman, A. Ramos, S.A. Kalogirou, N.J. Ekins-Daukes, C.N. Markides, Systematic testing of hybrid PV-thermal (PVT) solar collectors in steady-state and dynamic outdoor conditions, Appl. Energy 240 (2019) 1014-1030. https://doi.org/10.1016/j.apenergy.2018.12.049. 